\title{
Rice Commercialisation and Improved Agricultural Technology Adoption in Northern Ghana: Endogenous Switching Poisson Approach
}

\author{
(Research Article)
}

Kuzey Gana'da Pirincin Ticarileştirilmesi ve Gelişmiş Tarım Teknolojisinin Benimsenmesi: Içsel Anahtarlama Poisson Yaklaşımı

Doi: 10.29023/alanyaakademik.600275

\section{Samuel A. DONKOH}

Associate Professor of Agricultural Economics. Department of Agricultural and Resource Economics, Faculty of Agribusiness and Communication Sciences, University for Development Studies, P. O. Box TL 1882. Tamale, Ghana.

Email: sdonkoh@uds.edu.gh | Tel: +233245728465

Orcid No: 0000-0003-0054-705X

How to cite this article: Donkoh, S.A. (2020). Rice Commercialisation and Improved Agricultural Technology Adoption in Northern Ghana: Endogenous Switching Poisson Approach. Alanya Academic Review, 4(1),Page No. 105-121.

\author{
Keywords: \\ Adoption, \\ Endogenous Poisson \\ regression, Rice \\ commercialisation, \\ Improved \\ technologies, \\ Northern Ghana
}

Received:

01.08.2019

Accepted:

05.02.2020

\begin{abstract}
This study investigated the factors that influence the commercialisation drive and the effect on the adoption of improved agricultural technologies (IATs) using data collected from 543 farm households in northern Ghana. The method of analysis involved the estimation of Endogenous Poisson model. The findings indicate that commercialisation does enhance the adoption of IATs and is driven by factors such as: off-farm activities, rice output, sex, household headship, farm size, credit, commercial centre location. The probability of adopting IATs was also influenced by age, experience, mass media information sources, and home-to-farm distance. Stakeholders should target the youth and step up efforts in supporting flagship programmes such as the "Planting for Food and Jobs" and Planting for Export", while supporting livelihood diversification programmes.
\end{abstract}

\section{GİRIŞ̧}

Food supply must increase sustainably to match growing population especially across Africa. To this end, there is the need for agricultural policies to be harmonised with global, regional and national goals. Sustainable Development Goals (SDGs) 1 and 2 which focus on poverty alleviation and hunger eradication by the year 2030 (MoFA, 2017) are crucial if food security and welfare of people particularly, smallholder farmers in developing countries like Ghana are to be enhanced. Thus, increasing agricultural productivity through agricultural commercialisation and the adoption of improved production practices is key in meeting the SDGs 1 and 2. 
Rice is one of the major food security crops across the globe. The demand for the crop has given it a major priority in terms of research and per capita area under production. According to the Statistical, Research and Information Directorate (SRID) of MoFA (2017), Domestic rice production in Ghana has increased recently from 44\% in 2016 to $47 \%$ in 2017. Despite the increase in production, the Directorate stressed that Ghana still relies on rice import to meet the growing per capita consumption which currently stands at $35 \mathrm{~kg}$ annually. Selfsufficiency in rice production to meet the demand in Ghana is yet to be met, making the country to depend on imports of about $697,391 \mathrm{Mt}$ in 2016 alone to supplement what has been produced locally. To reduce rice importation, the government of Ghana and major stakeholders have invested quite substantially in agriculture. Farmers are motivated to venture into rice commercialization to increase productivity. Stakeholder investments and rice commercialization are expected to move Ghana towards self-sufficiency in rice production which should translate into alleviating poverty and eradicating hunger.

Historically, the agricultural industry in Ghana is predominantly led by smallholder farmers with average farm holding of less than 2.0 hectares. Smallholder farms are spread out across the country, making it difficult to reach by extension service providers and researchers who are in limited supply. Agriculture in Ghana is also heavily dependent on rain fall with only about $1 \%$ of the arable land being utilised by irrigation (Martey et al. 2012).

Current agricultural policy documents in Ghana (i.e. the Food and Agriculture Sector Development Policy, FASDEP I \& II) target commercial farming with the aim of increasing productivity. More attention has been given to rice production reflecting the significance of rice to fight food insecurity and alleviate poverty among poor farmers. Agricultural commercialisation has been keenly recognized to take place in four dimensions by producing a marketable surplus of traditional crops particularly rice; crop diversification; livelihood diversification and post-harvest handling strategies such as adding value to farm produce via processing (Kunze, 2003).

Agricultural commercialisation is a powerful tool to increase rural households' income and to ensure food security (Jaleta et al. 2009). It is a coping mechanism to reduce risks associated with crop production. Jaleta et al. (2009) stressed that farm commercialisation results in increased crop productivity through economies of scale, deeper learning through practice, frequent interaction, exposure to new innovations, and better motivations in the form of higher incomes, which translate into improved welfare gains for smallholder farmers.

Agricultural commercialisation has attracted donor support agencies (DFID, 2002) to scale-up crop production to fight food insecurity. Taking agriculture as business and building smallholder farmers' capacity are a strategic point to transform the agricultural industry in Ghana. For instance, the government of Ghana is promoting agricultural commercialisation to increase crop productivity through the "Planting for Food and Jobs" (PFJ) and "Planting for Export" (PfE) flagship programmes in collaboration with MoFA and donor agencies. Other organisations promoting agricultural commercialisation in Ghana are the National Seed Council (NSC), Ghana Commercial Agricultural Project (GCAP), Resilience in Northern Ghana (RING) project, Council for Scientific and Industrial Research (CSIR), and the Ghana Grains Council (GGC). The rest are RAINS, ACDEP, CARE International, Presbyterian Agricultural Services (PAS) and Peasant Farmers Association, among others. 
It is assumed in this study that agricultural commercialisation among smallholder farmers will lead to agricultural intensification and efficient use of resources. This is because commercialisation implies that the farmer must produce more in order to sell enough surplus for cash to meet his/her expenditures. Producing more in the phase of limited land resource implies the adoption of improved agricultural technologies such as improved seeds, fertilisers and other soil and water conservation practices. Thus, all other things being equal, a farmer with commercial orientation would adopt more improved agricultural technologies than a farmer with subsistence orientation.

In spite of the numerous organisations that have promoted agricultural commercialisation, it appears that there is still a wide gap between domestic demand and supply of rice in the country. Smallholder farmers in the country, particularly those in Northern Ghana still produce rice at subsistence level despite having the comparative advantage of producing the commodity in large quantities. Not much has been done to explore the potentials and drivers of commercialisation specifically, for rice production to increase productivity, to the best of the researcher's knowledge. Therefore, the aim of this paper is to examine the factors that influence farmers' participation in commercial rice production. The paper also assesses the innovative rice production practices among commercial and non-commercial rice farmers. The rest of the paper is organised as follows: section 2 gives a brief literature review, section 3 presents the methodology (including analytical framework), while the results and discussions are contained in section 4; and section 5 consist of conclusions and policy recommendations.

\section{BRIEF LITERATURE REVIEW}

Agricultural commercialisation can be explained as selling marketable surplus of farm produce (Rohana and Branda, 2010) to meet other expenditure of smallholder farmers. Rohana and Branda (2010) further explained that marketable surplus is the quantity of produce available for consumption by other people outside the farming family and raw materials for manufacturing and processing industries. Martey et al. (2012) also defined agricultural commercialisation as the transition from subsistence-oriented farming to marketoriented farming. This means that shifting the smallholder farmer's mind from subsistence farming to large scale farming, as he/she takes farming as a business, is the first step to agricultural commercialisation. Agricultural commercialisation has been well known to mean engaging in large scale farming, ignoring the fact that the smallholder farmers are cultivating crops such as rice for profit maximization, despite the small land holdings and constraints to resources such as cash security. What to produce and the purpose of production make a smallholder farmer allocate time for both labour and leisure differently in subsistence and commercialised farming.

AGRA (2017) distinguished among four categories of small farms as follows: commercial; pre-commercial; transition; and subsistence. On the extreme ends of the scale are commercial and subsistence farms that are oriented towards profit maximisation and producing for home consumption respectively. The farming system in between are either oriented towards commercialisation or subsistence. The organisation argued that it is necessary for governments to identify these different faring systems in order to formulate respective policies for each of them. 
According to IFAD-IFPRI (2011), agricultural commercialization is measured by the marketed surplus ratio. The marketed surplus ratio is defined as the value of crop sales as a percentage of the value of crop production. FAO (1989) revealed that subsistence farmers produce marketable surplus up to $25 \%$ of the total production; semi-commercial farmers produce marketable surplus between $25 \%$ to $50 \%$ of total production. Commercial farmers produce marketable surplus above $50 \%$ of the total production. IFAD-IFPRI (2011) revealed that the average marketed crop surplus ratio of the three (former) northern regions is about $22 \%$, which is $10 \%$ below the national average of $33 \%$.

Quite a number of studies have been carried out on agricultural commercialisation using IFAD-IFPRI's (2011) surplus ratio. For instance, a study on the extent of commercialisation of farming households in Nigeria was conducted by Ele et al. (2013). Using commercialisation household index, the researchers found that the degree of commercialisation was slightly above $60 \%$. Using Tobit regression model to investigate factors influencing farm household decision to commercialise, they found that total output, farming experience, extension service, farm area, membership in cooperatives and household size were the important factors influencing the degree of commercialisation. The researchers recommended that governments and stakeholders should come out with strategic policy plans to enhance food crop production and create a conducive environment for income generation.

Similarly, Kabiti et al. (2016) conducted an empirical study on factors influencing smallholder commercialisation of farming enterprises in Zimbabwe. Farm input and output commercialisation indices were computed for all the participating farmers and the Tobit model was used to regress the indices on farmer specific demographic factors. Their findings showed that the farmers were moderately commercialised for both input and output sides. However, the findings also revealed that different factors determined input and output commercialisation. The study concluded that smallholder farmers had a great potential for commercialisation if the necessary conditions and the right environment were provided. They recommended that both the public and private sectors should increase their contribution towards commercialisation through technical training backed by financial support.

Lastly, in Ghana, Martey et al. (2012) assessed commercialisation of smallholder agriculture, also using the Tobit regression model. The study assessed the trends in maize and cassava production by farm households; investigated the levels of commercialisation of these two crops and as well, examined the magnitude and direction of factors influencing intensity of commercialisation of the two crops. The findings showed that the degree of maize and cassava commercialisation were $53 \%$ and $72 \%$ respectively. This means that maize is mostly cultivated at subsistence level to meet household food security. Factors that were found to influence the extent of commercialisation were output price, farm size, access to extension services, distance to market and access to market information. The following recommendations for policy interventions were made. Agricultural extension agents should strengthen the business orientation of farm households with government support in terms of logistic supply and market infrastructure development; and government policy should target at creating friendly environment for private enterprise and/or entrepreneurs in the agribusiness sector to train farmers coupled with investment in irrigation schemes.

IFAD-IFPRI (2011)'s definition of commercialisation is to a large extent, a useful measure of commercialisation. It gives the observed quantities of farm produce that the farmer can supply to the market. The limitation with using observed values is that the determinants are 
not very useful in policy formulation. In the researcher's opinion what is more useful is to estimate the probability of a farmer going into commercialisation. Thus, in this study the dependent variable for a rice commercialisation model is a dummy variable defining the orientation of the farmer towards either commercialisation or subsistence. In this case a farmer was asked of his/her main motive of producing rice; whether it was for sale or for home consumption. In recent times, the extreme situations where the farmer produces rice for only home consumption or only the market is rare, the reality is that either the farmer sells more and consumes less or consumes more and sells less.

Rogers (2003) defined adoption as the extent to which recipients of a new technology or innovation use it. However, diffusion is when the use of the technology spreads in the community or society among many users. In this case, while adoption involves individual farmers, diffusion involves several farmers in the community or country. The importance of modern technology adoption is seen in the success of the Green revolution in Asia in the late 1960s where the production of cereals like wheat, rice and maize increased tremendously as a result of the adoption of improved seed varieties with the complementary inputs of fertilisers, insecticide, irrigation and mechanisation (Todaro and Smith, 2011). Unfortunately, SSA missed out due to several reasons, including the unsuitability of the improved seeds to the soils and climatic factors of the continent (Evenson and Gollin, 2000). In recent times, however, attempts have been made to re-introduce the Green revolution by the Alliance of Green Revolution in Africa (AGRA) with support from Kofi Annan Foundation and other stakeholders (Donkoh, 2011). One of the main lessons learnt is the development and adoption of technologies that are suitable to the land. That implies, as much as possible, improving upon existing technologies to enhance their productive capacities, rather than importing new technologies that may not be adaptable to the environment.

Like commercialisation, studies on agricultural technology adoption abound (e.g. Donkoh, 2011). In the empirical literature, some of the main determinants of technology adoption are formal education, access to credit and extension, training and membership to FBOs. However, to the best of the researcher's knowledge, not much has been done in terms of investigating the effect of farmers' commercialisation drive on improved agricultural technology adoption. This is the gap that the present study seeks to fill. The specific improved technologies and practices are nursery establishment, Harrowing, organic fertiliser, inorganic fertiliser (NPK), Fertiliser (Urea briquette), Puddling, Proper spacing $(20 * 20 \mathrm{~cm})$, Dibbling/drilling, early maturing variety, Drought tolerance variety, changing planting period and Bunding.

\section{MATERIALS AND METHODS}

\subsection{Studied Area, Sample Size and Survey Instruments}

The study was conducted in Northern Ghana, specifically using rice farmers from the (former) Northern and Upper East regions of Ghana. These two regions have suitable agricultural land for rice production and are the largest producers of rice in Ghana. This presents an opportunity to engage the teaming youth to go into rice commercialisation in the study area. The study employed multistage sampling technique to select the respondents. In the first stage, the two northern regions were purposively selected based on the recorded achievements in the rice production. Simple random sampling technique (using random table in excel) was employed to select the districts and the respondents for the study from a list of 
farm household obtained from MoFA. Sample size of 543 was arrived at by using Slovin's (1960) sample size calculation formula. Questionnaires were administered to the rice farmers through face to face interviews at the farmers' residence to protect the respondents' confidentiality.

\subsection{Data Analysis}

\subsubsection{Theoretical Model}

The methodological approach to the study draws inspiration from Terza (1998) and Miranda (2004). According to Terza (1998), given the ith farmer from a random sample $I=\{1 \ldots . . n\}$ conditional on a vector of explanatory variables $x_{i}$, an endogenous dummy $c_{i}$, and a random term $\varepsilon_{i}$, the dependent variable $y_{i}$, which is a count, is supposed to a follow a standard Poisson distribution as follows:

$$
f\left(y_{i} / \varepsilon_{i}\right)=\frac{\exp \left\{-\exp \left(x_{i}^{\prime} \beta+\gamma c_{i}+\varepsilon_{i}\right)\right\}\left\{\exp \left(x_{i}^{\prime} \beta+\gamma c_{i}+\varepsilon_{i}\right)\right\}^{y_{i}}}{y_{i} !}
$$

where $\beta$ and $\gamma$ are coefficient to be estimated. The error term $\varepsilon_{i}$ measures omitted and unobserved variables as well as any measurement error. Given a vector of explanatory variables $z_{i}$ (which may contain some or all elements of ) $x_{i}, c_{i}$ is characterised by an index process $c_{i}= \begin{cases}1 & \text { if } z_{i} \alpha+v_{i}>0 \\ 0 & \text { otherwise }\end{cases}$

where $\alpha$ is a vector of coefficients to be estimated. Suppose that $w_{i}$ represent all endogenous variables and $\varepsilon_{i}$ and $v_{i}$ are jointly normal with mean zero and covariance matrix $\sum=\left(\begin{array}{cc}\sigma^{2} & \sigma p \\ \sigma p & 1\end{array}\right)$, given that $\varepsilon_{i}, c_{i}$ and $y_{i}$ are independent. Hence, the joint conditional probability density function of $y_{i}$ and $c_{i}$, given $w_{i}$, can be written as

$$
\begin{aligned}
f\left(y_{i}, c_{i} / w_{i}\right)= & \int_{-\infty}^{\infty}\left\{c_{i} f\left(y_{i} / c_{i}=1, w_{i}, \varepsilon_{i}\right) \operatorname{Pr}\left(c_{i}=1 / w_{i}, \varepsilon_{i}\right)\right. \\
& \left.+\left(1-c_{i}\right) f\left(\left(y_{1} / c_{1}=0, w_{i}, \varepsilon_{i}\right)\right) \operatorname{Pr}\left(c_{i}=0 / w_{i}, \varepsilon_{i}\right)\right\} f\left(\varepsilon_{i}\right) c_{i} \varepsilon_{i}
\end{aligned}
$$

where $f\left(\varepsilon_{i}\right)$ denotes the probability density function for the random term $\varepsilon_{i}$. 


\subsubsection{Empirical Model}

Following from the theoretical equation 1 and given the objectives of the study, namely: to investigate the factors influencing rice commercialisation; and to determine the effects of rice commercialisation on the adoption of improved agricultural technologies, there are two equations to be estimated; rice commercialisation and improved agricultural technology equations, and therefore two dependent variables. Since rice commercialisation drive is assumed to influence the adoption of improved technologies, the latter equation may be said to be the substantive equation and the former the selection equation in a recursive framework (i.e. Commercialisation influences adoption but not the other way round).

Thus, given equation 1 above, the dependent variable $\left(y_{i}\right)$ of this study is the number of improved farm practices (IATs) that a farmer adopts. It is a count variable, and therefore, follows the Poisson distribution. This is hypothesised to be determined by rice commercialisation $\left(c_{i}\right)$ as well as some farm and farmer characteristics and institutional variables $\left(x_{i}\right) . C_{i}$ is also influenced by some farm and farmer characteristics as well as institutional variables, which, for the purposes of distinction are represented by $z_{i}$. Clearly, there may be some unobserved variables that determine both $y_{i}$ and $c_{i}$ such that if we estimate the equations for the two variables separately, we may not be able to measure the true effect of $z_{i}$ and other variables on $y_{i}$. For example, innovativeness, on the part of a farmer may lead him/her to adopt an IAT.

Similarly, this quality may influence his/her commercialisation drive in a positive way. In this case, it becomes difficult to separate the effect of the farmer's innovativeness on his/her adoption behaviour from the effect of commercialisation on his/her adoption behaviour. In other words, if per chance, after the estimation of the two equations separately, we find that commercialisation has impacted significantly on adoption, how do we know whether it is the farmers' commercialisation drive or innovativeness that is responsible? Terza's (1998) model offers a solution like that of Heckman's (1979) treatment effect model that corrects for selectivity bias problems in some simultaneous equation models. It should however, be noted, that it is not automatic that there is endogeneity between adoption and commercialisation. Miranda (2004) has given a good illustration of the test that shows whether the selection variable (commercialisation in this study) is endogenous or exogenous. Either way, Miranda (2004) suggested estimation packages that are similar but not exactly, the same (see Miranda, 2004; pp 45\&46).

The empirical model to be estimated to measure the effect of rice commercialisation on the adoption of IATs is given as follows:

Commercialisation $=\alpha_{0}+\alpha_{1}$ Sex $+\alpha_{2}$ Age $+\alpha_{2}$ Edu $+\alpha_{3}$ FarmSize $+\alpha_{4} F B O+\alpha_{5}$ Output $+\alpha_{6}$ Credit $+\alpha_{7}$ Off - farm $+\beta_{8}$ Farm $_{\text {Dist }}+\alpha_{9}$ Media $+\alpha_{10}$ HHhead $+\alpha_{12}$ Region $+V_{i}$

Adoption $=\beta_{0}+\beta_{1}$ Age $+\beta_{2}$ Experience $+\beta_{2}$ Off_farm $+\beta_{3}$ Credit $+\beta_{4} F B O+\beta_{5}$ Livestock + $\alpha_{6}$ Farm_Dist $+\beta_{7}$ Media $+\beta_{8}$ Commercialisation $+\varepsilon_{i}$

The measurement and a priori expectations of the variables are indicated in Table 1. 
Table 1. Description and Measurement of Variables

\begin{tabular}{|c|c|c|c|}
\hline Variable & Description & Measurement & $\begin{array}{l}\text { Expected } \\
\text { sign }\end{array}$ \\
\hline \multicolumn{4}{|c|}{ Dependent variable } \\
\hline $\begin{array}{l}\text { Commercialisation } \\
\text { (RC) }\end{array}$ & $\begin{array}{l}\text { Farmer's main reason for rice } \\
\text { cultivation }\end{array}$ & $\begin{array}{l}\text { Dummy: } 1=\text { for profit } 0 \\
=\text { for subsistence }\end{array}$ & $\begin{array}{c}+ \\
\text { (Adoption) }\end{array}$ \\
\hline \multicolumn{4}{|c|}{ Independent variables } \\
\hline Sex & Sex of respondent & $\begin{array}{l}\text { Dummy: } 1=\text { male, } 0= \\
\text { female }\end{array}$ & $+/-$ \\
\hline Age & Age of respondent & Years & $+/-$ \\
\hline Education & Farmer's years of education & Years & + \\
\hline Experience & Farmer's years in rice cultivation & Years & $+/-$ \\
\hline Off-farm & $\begin{array}{l}\text { Farmer's engagement in off-farm } \\
\text { employment }\end{array}$ & $\begin{array}{l}\text { Dummy: } 1=\text { yes, } 0= \\
\text { otherwise }\end{array}$ & $+/-$ \\
\hline Farm size & Rice farm size & Acres & $+/-$ \\
\hline Credit & Access to credit/loan & $\begin{array}{l}\text { Dummy: } 1=\text { yes, } 0= \\
\text { otherwise }\end{array}$ & + \\
\hline Livestock & Livestock ownership & $\begin{array}{l}\text { Dummy: } 1=\text { yes, } 0= \\
\text { otherwise }\end{array}$ & + \\
\hline Rice output & $\begin{array}{l}\text { Quantity of rice harvested per acre } \\
\text { by farmer }\end{array}$ & $\mathrm{Kg}$ & + \\
\hline Household-head & $\begin{array}{l}\text { Farmer's status at the household } \\
\text { level }\end{array}$ & $\begin{array}{l}\text { Dummy: } 1=\text { Head, } 0= \\
\text { otherwise }\end{array}$ & $+/-$ \\
\hline FBO & $\begin{array}{l}\text { Farmer's membership to farmer- } \\
\text { based organisation (FBO) }\end{array}$ & $\begin{array}{l}\text { Dummy: } 1=\text { yes, } \quad 0= \\
\text { otherwise }\end{array}$ & + \\
\hline Region & Farmer's location & $\begin{array}{l}\text { Dummy: } 1=\text { Upper east, } \\
0=\text { Northern }\end{array}$ & $+/-$ \\
\hline Media & $\begin{array}{l}\text { Heard rice commercialisation in } \\
\text { media by respondent }\end{array}$ & $\begin{array}{l}\text { Dummy: } 1=\text { yes, } \quad 0= \\
\text { otherwise }\end{array}$ & + \\
\hline Farm distance & Farm plot distance to home & In kilometres & + \\
\hline
\end{tabular}

Note: The expected sign is assumed to be the same for both commercialisation and adoption Source: Author's construct, 2019

\section{RESULTS AND DISCUSSION}

\subsection{Demographic and Socioeconomic Characteristics of Sampled Farmers}

Table 2 presents the results of the descriptive statistics of the sampled rice farmers. Out of the 543 rice farmers, about 65.19 percent had a commercial motive for producing rice. About 84.7 percent and 80.4 percent were found to be male for the commercial and non-commercial rice farmers respectively. On average, (in the pooled data) about 83 percent of the respondents were male. Age the average age for commercial and non-commercial farmers was found to be 38.3 and 38.9 years respectively. 
About 54.1 percent of the commercial rice farmers were household heads while 66.1 percent of the non-commercial rice farmers were household heads. In terms of education, commercial rice farmers had a marginally higher education compared to their noncommercial counterparts. The mean educational level was about 4 years. Commercial rice farmers had about 11 years of rice cultivation experience compared to non-commercial rice farmers who had about 13years cultivation experience. There was also a significant difference in the production of livestock between commercial $(63.3 \%)$ and non-commercial farmers $(74.1 \%)$.

About 27 percent of commercial rice farmers were into off-farm businesses, as against 25.9 percent for non-commercial rice farmers. The average land holding was found to be significantly higher for commercial rice farmers (2.96 acres) compared to non-commercial rice farmers (1.75). Meanwhile, the average rice farm size in the study area is 2.37 acres. About 32 percent of the respondents were in the Upper East region as against 68 percent in the northern region. The results further show that about 64 percent of the respondents who were commercial rice farmers belonged to FBOs while 63 percent of the non-commercial farmer category also belong to an FBO. Moreover, commercial rice farmers received significantly less agricultural extension visits (about 2 times) compared to non-commercial counterparts who had about 6 visits per annum.

On the average, commercial farmers were closer to market centres than non-commercial rice farmers $(7.5 \mathrm{~km})$. Access to production credit was very low as only 11.8 percent of farmers had access to credit. Lastly, farmers who practiced irrigation constituted 58.9 percent. Specifically, 64.4 percent of commercial rice farmers practiced irrigation while 48.7 percent of non-commercial rice farmers practiced same. Also, ironically, a higher percentage of noncommercial farmers $(83.6 \%)$ received information from the mass media than their commercial rice producing counterparts $(71.8 \%)$.

Table 2. Demographic and Socioeconomic Characteristics of the Respondents

Variable Commercial Non-commercial Mean difference Pooled data t-value

\begin{tabular}{lccccc}
\hline RC & $354(65.19 \%)$ & $189(34.81 \%)$ & & & \\
\hline Sex & 0.847 & 0.804 & -0.043 & 0.830 & -1.284 \\
Age & 38.30 & 38.90 & 0.61 & 38.49 & 0.638 \\
Household-head & 0.531 & 0.661 & $0.130^{* * *}$ & 0.576 & 2.945 \\
Education & 4.285 & 3.598 & -0.687 & 4.046 & -1.490 \\
Livestock & 0.633 & 0.741 & $0.108^{* * *}$ & 0.670 & 2.560 \\
Experience & 11.034 & 13.016 & $1.982^{* * *}$ & 11.724 & 2.891 \\
Off-farm business & 0.274 & 0.259 & -0.015 & 0.269 & -0.338 \\
Farm size & 2.694 & 1.749 & $-0.945^{* * *}$ & 2.365 & -3.655 \\
Region & 0.311 & 0.338 & 0.028 & 0.320 & 0.663 \\
Membership of FBO & 0.638 & 0.630 & -0.009 & 0.635 & -0.202 \\
media & 0.718 & 0.836 & $0.118^{* * *}$ & 0.759 & 3.095 \\
Farm-market-distance & 6.092 & 7.498 & $1.406^{* * *}$ & 6.581 & 3.114
\end{tabular}


Note: *** denotes 1 percent significant level

Source: STATA estimates. Field data, 2018

\subsection{Comparison of Improved Technologies Adoption Levels Among Commercial and Non-Commercial Rice Farmers}

Adoption of good agronomic practices and improved rice production technologies is critical in enhancing productivity and attaining self-sufficiency in the production of rice. Increased rice productivity means less poverty and food insecurity. This section discusses the levels of adoption of good agronomic practices and improved rice technologies by comparing commercial and non-commercial rice farmers. In all, 34.8 percent, representing 189 farmers had subsistence orientation while the remaining 65.2 percent, representing 354 had commercial orientation. By considering the Chi2 statistics in Table 3, there is a revelation of significant statistical differences in the adoption levels between commercial and noncommercial rice farmers. The results from Table 3 reveal that majority (about $76 \%$ ) of commercial rice farmers practiced nursery establishment as against only 24.3 percent for noncommercial rice farmers. Establishment of rice nursery is very important in rice cultivation as it helps to raise seedling for transplanting and to re-fill or replant in circumstances of crop loss. Failure of some rice seeds to germinate due to environmental and genetic factors could result in reduced rice population density on the field, which has a potential negative effect on yield. Farmers overcome this low rice population density by establishing rice nursery to refill the potholes in order to enhance productivity. About 57 percent of commercial rice farmers practiced harrowing compared to 42.6 percent for non-commercial rice farmers. Harrowing by tractor helps in loosening the soil, thereby increasing the porosity and water absorption capabilities.

Organic manure has widely been used in upland agriculture for the production of maize, groundnut, pepper and vegetables. The use of organics has not been widely associated with lowland rice production, especially in the study area. But in recent times, manure has been applied to lowlands to boost rice production as a sustainability measure and to improve soil structure. In this study, 56.5 percent of commercial rice farmers had applied organic manure on their rice fields. Just about $44 \%$ of non-commercial rice farmers applied some organics to their farms. While about 80 percent of commercial rice farmers adopted puddling to level their farms for better circulation of water, just 19.8 percent of non-commercial rice farmers adopted this important practice.

Commercial rice farmers who practiced line planting represent 69.8 percent compared to 30.2 percent for non-commercial rice farmers. Farmers might plant rice in lines without necessarily following proper spacing which also improves soil aeration. Commercial rice farmers who practiced proper spacing $(20 * 20 \mathrm{~cm})$ was found to be 68.3 percent as against 31.7 percent for non-commercial farmers. Out of the total sampled, about 52 percent of the commercial farmers practiced dibbling/drilling, showing a marginal difference with noncommercial farmers which was found to be 48 percent.

Inorganic fertilizer is one of the soil fertility enhancement technologies advocated by scientists to increase agricultural productivity. Application of appropriate amounts of NKP as basal and urea for top dressing has been found to have significant effect on yields of rice farmers. The study found a high percentage of commercial rice farmers using NPK $(62.7 \%)$ 
and urea briquettes (71.3\%). Comparatively, just about 37 percent and 29 percent of noncommercial farmers applied NPK and urea briquettes respectively to their rice farms. Urea briquette is compact form of urea known to have some environmental benefits because of its mode of application that prevents wastage and seepage into water bodies. The targeted application of urea briquette also enhances effectiveness and efficiency of nutrient use by the rice plant. The results present an indication that inorganic fertilizers were patronised more by commercial rice farmers than non-commercial farmers in the study area.

Also, about 60 percent and 47 percent of commercial rice farmers adopted early maturity and drought tolerance rice varieties respectively. On the other hand, 39.7 percent and 52.9 percent of non-commercial farmers adopted early maturity and drought tolerance rice varieties respectively. In addition, 60.5 percent of commercial rice farmers' changed planting period in the regime of planting season while 39.5 percent of non-commercial farmers changed rice planting period. Rice farmers change planting period in order to adapt to climate change and climate variability. The irregular pattern of rainfall makes farmers to adjust the planting period to meet good rains. Some of the farmers resorted to weather forecast by the Meteorological Service of Ghana while others resorted to unscientific individual climate monitoring process. As rational beings, farmers do not just start to cultivate immediately the raining season sets in but will wait and observe the pattern for a while before proceeding with planting. This helps the farmers to escape the phenomenon of long drought period which sometimes leads to total loss of crops.

Bunding is water harvesting technique to support rice growth and development especially when there is a problem of drought. More commercial rice farmers (69.2\%) were found to have adopted this water harvesting technique, compared with only 30.8 percent noncommercial farmers. In terms of rice output, commercial farmers achieved significantly higher output $(3322.54 \mathrm{~kg}(3.32 \mathrm{Mt})$, than non-commercial rice farmers who had average output of $1490.44 \mathrm{~kg}(1.49 \mathrm{Mt})$.

Table 3. Adoption Levels of Improved Rice Production Technologies and Output

\begin{tabular}{lcccccc}
\hline \multirow{2}{*}{ Agronomic Practices K } & \multicolumn{2}{c}{ Commercialization } & Non-commercialization & Ch $^{2}$-Value & Pr.-value \\
\cline { 2 - 5 } & Freq. & $\%$ & Frequency & $\%$ & & \\
\hline Nursery establishment & 243 & 75.70 & 78 & 24.30 & $38.202^{* * *}$ & 0.000 \\
Harrowing & 136 & 57.40 & 101 & 42.60 & $11.303 * * *$ & 0.001 \\
Organic use & 87 & 56.50 & 67 & 43.50 & $7.170^{* * *}$ & 0.007 \\
Puddling & 97 & 80.20 & 24 & 19.80 & $15.380^{* * *}$ & 0.000 \\
Line planting & 196 & 69.80 & 85 & 30.20 & $5.331^{* *}$ & 0.021 \\
Proper spacing (20*20cm) & 196 & 68.30 & 91 & 31.70 & $2.577 *$ & 0.108 \\
Dibbling/drilling & 79 & 52.00 & 73 & 48.00 & $16.257 * * *$ & 0.000 \\
Fertilizer (NPK) & 266 & 62.70 & 158 & 37.30 & $5.149 * *$ & 0.023 \\
Fertilizer (Urea briquettes) & 134 & 71.30 & 54 & 28.70 & $4.690^{* *}$ & 0.030 \\
Early maturing variety & 155 & 60.30 & 102 & 39.70 & $5.125^{* *}$ & 0.024 \\
\hline
\end{tabular}




\begin{tabular}{lcccccc}
\hline Drought tolerance variety & 48 & 47.10 & 54 & 52.90 & $18.202^{* * *}$ & 0.000 \\
Changing planting period & 158 & 60.50 & 103 & 39.50 & $4.803^{* *}$ & 0.028 \\
Bunding & 191 & 69.20 & 85 & 30.80 & $3.977 * *$ & 0.046 \\
Rice output $(\mathrm{Kg})$ & \multirow{2}{*}{3322.54} & \multicolumn{2}{c}{1490.44} & $5.141 * * *$ & 0.000
\end{tabular}

${ }^{\mathrm{K}}$ This was multiple response, so farmers could choose as many as applied to them. Significant effects are indicated with *, p <0.1;**, p <0.05; ***, p <0.01.

Source: STATA estimates. Field data, 2018

Turning to Table 4, we observe the intensity of adoption vis-à-vis the percentage of adopters. We observe that the highest percentage of adopters (14.73) adopted 8 of the technologies, followed by $14.0 \%$ who adopted 6 technologies. The third highest percentage of adopters $(13.63 \%)$ adopted 5 technologies while the fourth (9.39) and fifth (9.02) highest percentages adopted 9 and 12 technologies respectively. Only $1.84 \%$ (i.e.10 farmers) did not adopt any of the technologies. The rest are as indicated in the Table.

Table 4. Percentage Distribution of Adoption Intensity

\begin{tabular}{ccc}
\hline Adoption intensity & Frequency & Percentage \\
\hline 0 & 10 & 1.84 \\
1 & 1 & 0.18 \\
2 & 14 & 2.58 \\
3 & 26 & 4.79 \\
4 & 37 & 6.81 \\
5 & 74 & 13.63 \\
6 & 76 & 14.00 \\
7 & 42 & 7.73 \\
8 & 80 & 14.73 \\
9 & 51 & 9.39 \\
10 & 36 & 6.63 \\
11 & 19 & 3.50 \\
12 & 49 & 9.02 \\
13 & 16 & 2.95 \\
14 & 12 & 2.21 \\
\hline Total & 543 & 100.00 \\
\hline
\end{tabular}

Source: STATA estimates. Field data, 2018

\subsection{Factors Influencing the Commercialisation Drive of Farmers}

The objectives of the study were to investigate the factors influencing the commercialisation drive of farmers and the effect of commercialisation on the adoption of IATs. From the methodology section, we noted that the estimation of endogenous Poisson model would be most appropriate because it corrects for selectivity bias problems that may arise as a result of some observed and unobserved factors that may influence both commercialisation and adoption.

Following Miranda (2004), two sets of equations were estimated; one assumed endogeneity of the commercialisation variable while the other assumed exogeneity. In general, the coefficients in Panel A are almost the same as those in Panel B. However, the results in Panel A are preferred to those in B because in Panel A selectivity bias has been corrected for. In Panel A, the estimation results show a significant Rho and sigma, implying that 
commercialisation and adoption variables are correlated, and that the data was also overdispersed and required the estimation of an appropriate regression model, namely; Endogenous Switching Poisson model. Thus, it can be concluded that commercialisation is endogenous. Being a Poisson (count) model, the coefficients are relevant as opposed to the other limited dependent-variable models in which the marginal effects are crucial.

The second part of the estimation results in Table 4 relate to the commercialisation variable. Household headship was negative and highly significant at 1 percent level. The negative sign of the variable implies that farmers who are not heads of their families are more oriented towards commercialisation, compared with farmers who are heads of their families. The latter are more oriented towards food security than cash security and therefore are more into subsistent farming. Another group of farmers who are more into subsistent farmers, per the estimation results, are female farmers. The positive coefficient of the sex variable implies that male famers have greater probability of going into commercial farming than their female counterparts. This is also plausible; women are more directly into providing food to the household than men and are usually involved in off-farm ventures. They are also more involved in the post-harvest management activities than their male counterparts and will seldom invest in production activities especially on a commercial level. Women are generally disadvantaged in accessing production technologies such as fertilizers and improved seeds for commercial production purpose. Similar findings were made by Mulwa et al. (2017) and Ragasa et al. (2013).

Other results that met the researcher's a priori expectations are the positive coefficients of off-farm and rice output, as well the negative coefficient of region (location). Engagement in off-farm activities on the part of the farmer is a sign of his/her business orientation. Such business orientation is likely to manifest also in the farmer's production business. Normally, engagement in off-farm activities would give the farmer other sources of income to enable $\mathrm{him} / \mathrm{her}$ to invest in their farm business. This finding corroborates with Martey et al. (2012) who found that off-farm income increases the probability of farmers to practice agricultural commercialisation. Increase in output is also supposed to motivate farmers to invest more in agricultural activities. So, it was plausible to find that farmers with increased output had a higher probability of going into commercial rice production. It may well also be that most farmers with a commercial drive will necessarily increase their farm sizes which could eventually lead to increases in output. Contrary to the a priori expectation however, farmers with smaller farm sizes had a higher probability of going commercial.

The probability of going commercial is also higher for farmers in the northern region than those in the Upper East region. This is also plausible because, the Northern region is generally more developed and accessible, and therefore more commercialised than the Upper East region. The coefficient of credit did not also meet the a priori expectation. The a priori expectation was that accessing credit would enhance the probability of going into commercialisation because, generally business oriented person are more interested in accessing credit than non-business persons. Abu (2015) found a positive effect of credit on the intensity of market participation. 
Table 5. Full Maximum Likelihood Estimation of the Effect of Commercialisation on the Adoption of Improved Technology Adoption in Northern Ghana



Source: STATA estimates. Field data, 2018

\subsection{Factors Influencing the Adoption of Improved Agricultural Technologies}

Turning to the estimation results of the adoption of improved agricultural technologies in the first part of Table 4, five of the variables were found to be significant. These are age, experience, rice commercialisation, access to mass media extension, and farm-home distance. The main objective of the study was to determine the effect of rice commercialisation on the adoption of IATs. The positive coefficient of the commercialisation variable means that farmers who were commercially oriented had higher probability of adopting IATs than those who were subsistent oriented. This is a very important finding because, as indicated earlier, the vision for Ghana's agriculture is to modernise agriculture by improved or modern inputs so that production is unscaled, and markets are expanded. In Abdullah et al. (2019), farmers 
who had higher probability of going into commercialisation had a greater welfare than subsistent oriented farmers.

The positive coefficients of the age and experience of the farmer indicate that farms managed by the old, and those with long year of rice production experience have a higher probability of adoption than those managed by the relatively young persons, and with less years of experience in rice production. This finding corroborates with Donkoh, Azumah, and Awuni (2019) but is in contrast with that of Melesse (2018) which shows a negative relationship between age and the adoption of improved production technologies. The positive coefficient of media also indicates that farmers who have the benefit of getting information from the mass media such as radio and television have higher probability of adopting many IATs than their counterparts with less mass media contacts. This finding is also consistent with Awuni, Azumah, and Donkoh (2018) who also found mass media extension mechanisms to positively and significantly influence the adoption of multiple technologies by rice farmers in northern Ghana.

The only significant variable with a negative relationship with the adoption of IATs is distance from home to farm. The negative coefficient implies that the probability of adopting IATs is higher when the farmer's farm is closer to his/her house than when the farm is at a remote place. This is also plausible because when the farmer's plot is closer, he/she is able to transport technologies/inputs easier and faster to the farm than when it is far away.

\section{CONCLUSIONS AND RECOMMENDATIONS}

The study sought to investigate the factors that influence the commercialisation drive and its effect on the adoption of IATs in the (former) Northern and Upper East Regions of Ghana. The methods of analysis involved the estimation of an endogenous switching Poisson model and descriptive statistics such as the chi square. The estimation results of the endogenous Poisson regression model indicated that the probability of commercialisation was higher for the following categories of farmers: male farmers; farmers with higher output; farmers engaged in off-farm activities; farmers with smaller farm size and without access to farm credit; farmers who are not household heads; and farmers living in the Upper East region opposed to living in the northern region. The probability of adopting IATs was also higher for the following categories of farmers: farmers with higher commercialisation drive; older and experienced farmers; farmers with access to mass media extension methods; and farmers with relatively shorter distance between their homes and their farms.

The findings of the study give some insight into the angle from which government and other stakeholders can pursue the vision of a modernised agriculture with high commercialisation drive. Commercialisation enhances adoption of IATs. However, commercialisation is itself driven by factors such as engagement in off-farm activities, output, farm size and living in a commercial centre/region. Government should target the youth and step up efforts in supporting its flagship programmes, "Planting for Food and Jobs" and "Planting for Exports." NGOs should also step up their efforts in helping the farmers to diversify their livelihoods. Proceeds from off-farm activities ease the pressure on farm revenue and give the farmer the financial ability to engage in commercialisation and the adoption of IATs. Commercial towns or regions are also places that stakeholders can target if farmers' commercialisation drive is to be enhanced. This is because in such places, there are backward and forward linkages which could explain why the probability of commercialisation in this study was higher in the 
northern region than in the Upper East region. These notwithstanding, other categories of farmers such as female farmers, the aged and more experienced farmers cannot be neglected. Affirmative action in terms of resource distribution should be taken for such farmers.

In terms of methodology, the addition to knowledge is the fact that the study estimated a probability of farmers' commercialisation drive, rather than the amount of market surplus. Another area of difference is that the study measured the effect of commercialisation on technology adoption. In most studies, the substantive equation is the intensity of adoption. Lastly, the use of Terza and Miranda methodologies is quite uncommon.

\section{ACKNOWLEDGEMENTS}

The author acknowledges the contribution of Shaibu Baanni Azumah for helping in the data collection and management processes. The support of all the respondents (rice farmers) in northern Ghana is also acknowledged.

\section{REFERENCES}

ABDULLAH, RABBI, R. AHAMED, R, ALI, S. CHANDIO, A.A., AHMED, W, IIYIS, A., \& DIN, I.U. (2019). Determinants of commercialisation on the welfare of smallholder rice farmers by using Heckman two stage approach. Journal of the Saudi society of Agricultural Science 18, 224-233.

ABU, B.M. (2015). Groundnut market participation in the Upper West Region of Ghana. Ghana Journal of Development Studies 12, (1\&2).

AGRA. (2017). Africa agriculture status report: The business of smallholder agriculture in Sub-Saharan Africa. Nairobi, Kenya: Alliance for a Green Revolution in Africa (AGRA). Issue No. 5

AWUNI, J.A., AZUMAH, S.B., \& DONKOH, S.A. (2018). Drivers of Adoption Intensity of Improved Agricultural Technologies Among Rice Farmers: Evidence from Northern Ghana. Review of Agricultural and Applied Economics, 21 (2): 48-57.

DFID. (2002). Eliminating hunger: Strategy for achieving the millennium development goal on hunger. DFID. London. May.

DONKOH, S. A. AZUMAH, S. \& AWUNI, J.A (2019) Adoption of improved agricultural Technologies among Rice Farmers in Ghana: A Multivariate Probit Approach. Ghana Journal of Development Studies 3(16): 46-67.

DONKOH, S.A. (2011). Technology Adoption and Efficiency in Ghanaian Agriculture: A Microeconomic Study: USA LAMBERT Academic Publishing.

ELE, I. E., OMINI, G. E. \& ADINYA, B. (2013). Assessing the extent of commercialization of smallholding farming households in Cross River State, Nigeria. Journal of Agriculture and Veterinary Science, 4(2): 49-55.

EVENSON, R. E, \& GOLLIN, D. (2000). The Green Revolution: an end of century Perspective. Available http://www.williams.edu/economics/wp/gollin\%20The\%20green\%20revolution.

FOOD AND AGRICULTURE ORGANISATION (FAO) (1989). Horticultural marketing: A resource and training manual for extension officers, Rome.

HECKMAN, J. J. (1979). Sample selection bias as a specification error. Econometrica 47(1): $153-161$. 
IFAD-IFPRI (2011). Agricultural commercialization in northern Ghana. Innovative policies on increasing access to markets for high-value commodities and climate change mitigation. IFAD-IFPRI Partnership Newsletter. Retrieved from http://ifadifpri.wordpress.com.

JALETA, M., GEBREMEDHIN, B. \& HOEKSTRA, D. (2009). Smallholder commercialization: processes, determinants and impact. Discussion Paper No. 18. Improving Productivity and Market Success (IPMS) of Ethiopian Farmers Project, ILRI (International Livestock Research Institute), Nairobi, Kenya.

KABITI, H.M., RAIDIMI, N.E., PFUMAYARAMBA, T.K. \& CHAUKE, P.K. (2016). Determinants of agricultural Commercialization among smallholder farmers in Munyati resettlement area, Chikomba district, Zimbabwe. Journal of Human Ecology 53(1): 10-19

KUNZE, D. (2003). Challenges and critical issues of small farm Commercialisation of agriculture. Proceedings of the International Workshop on Gender Impacts of Commercialization of Smallholder Agriculture. 14-16, IITA, Ibadan.

MARTEY, E., AL-HASSAN, R. M. \& KUWORNU, J. K. M. (2012). Commercialization of smallholder agriculture in Ghana: A Tobit regression analysis. African Journal of Agricultural Research 7(14):2131-2141.

MELESSE B. (2018). A Review on Factors Affecting Adoption of Agricultural New Technologies in Ethiopia. Journal of Agricultural Science and Food Research, 9: 22

MINISTRY OF FOOD AND AGRICULTURE (MOFA) (2017). Agricultural Sector Progress Report 2017. MoFA, Accra, Ghana.

MIRANDA, A. (2004). FIML estimation of an endogenous switching model for count data. The Stata Journal 4(1): 40-49

MULWA, C., MARENYA, P., RAHUT, D.B. \& KASSIE, M. (2017). Response to climate risks among smallholder farmers in Malawi: A multivariate probit assessment of the role of information, household demographics, and farm characteristics. Climate Risk Management, 16 (1): 208-221.

RAGASA, C., DANKYI, A., ACHEAMPONG, P., WIREDU, A.N., CHAPOTO, A., ASAMOAH, M. \&TRIPP, R. (2013). Patterns of adoption of improved rice technologies in Ghana. International Food Policy Research Institute Working Paper, 35: 6-8.

ROGERS, E.M. (2003). Diffusion of Innovations, 5th Edition, New York, Free Press.

ROHANA, M.R.P \& BANDRA, R. (2010). Commercialisation of Agriculture and role of Agricultural Extension. Sabaragamuwa University Journal, 6:1-13

SLOVIN, E. (1960). Slovin's formula for sampling technique. Retrieved from https://edoc.pub/the-slovin-formula-pdf-free.html.

TERZA, J. (1998). Estimating count data models with endogenous switching: Sample selection and endogenous treatment effects. Journal of Econometrics, 84: $129-154$.

TODARAO, M. P., \& SMITH, S. C. (2011). Economic development, $11^{\text {th }}$ Edition. England, Pearson Education Ltd. 